\title{
Biotech slumps in Q1
}

\section{Stacy Lawrence}

Amid global economic uncertainty, biotech indices and financing slumped in the first quarter. Overall, financing was the lowest in 18 months, off by more than half from a Q207 peak, with reductions in every category, except debt. Public floatations dried up almost

\section{Biotech stock market performance}

Most indices are back to where they were a year ago after a double-digit ride up last fall; the Swiss Exchange has fared particularly badly.

- Swiss Exchange Nasdaq Composite E S\&P 500 Dow Jones Nasdaq Biotech BioCentury 100

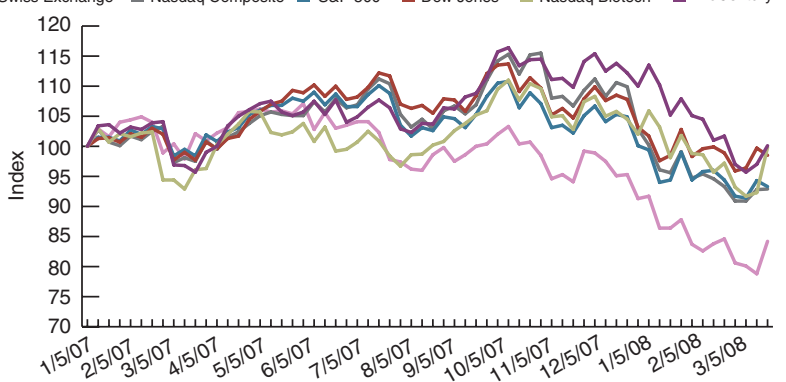

Source: Multex, $\mathrm{BCIQ}$ : BioCentury Online Intelligence

\section{Global biotech industry financing}

Every financing category dropped dramatically last quarter, except for debt. This is the 3rd consecutive down-quarter and the lowest since Q306.

- Partnership Debt and other financing Venture capital Follow-on financing $\quad$ PIPEs IPOs

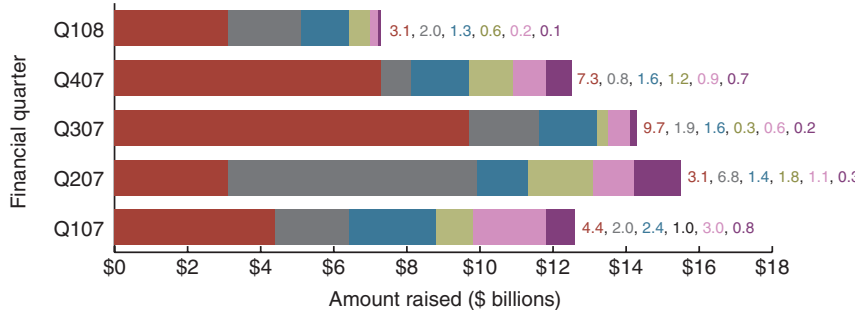

Partnership figures are for deals involving a US company. PIPEs, private investment in public equity. IPOs, initial public offerings. Source: BCIQ: BioCentury Online Intelligence, Burrill \& Company. entirely, with only two offerings making it out last quarter. Venture capital fundraising, a delayed indicator of the state of biotech financing, performed somewhat better but was still down by about one-fifth.

\section{Global biotech initial public offerings}

The IPO window has all but slammed shut in the current volatile economy.

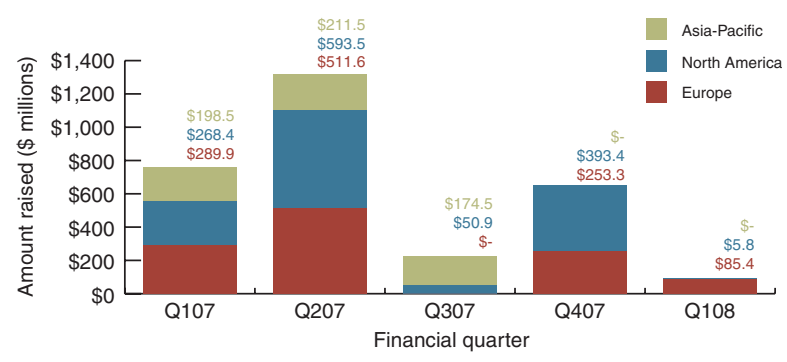

\section{Number of IPOs}

Asia-Pacific

Europe

Source: $\mathrm{BCIQ}$ : BioCentury Online Intelligence

\section{Global biotech venture capital investment}

VC funding was the lowest since Q105, down about one-fifth from Q407 and almost half from Q107.

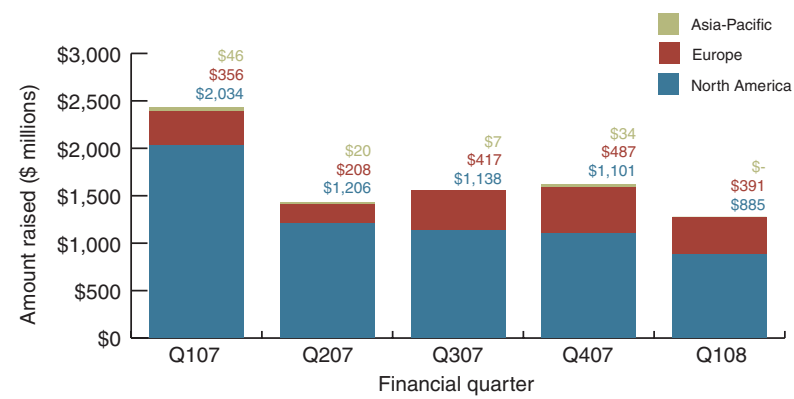

Source: $\mathrm{BCIQ}$ : BioCentury Online Intelligence

Notable Q1 biotech deals

\begin{tabular}{|c|c|c|c|c|}
\hline IPOs & Company & Amount raised ( $\$$ millions) & Percent change in stock price since offer ${ }^{\mathrm{a}}$ & Date launched \\
\hline & MolMed & 85.4 & $-2 \%$ & $29-\mathrm{Feb}$ \\
\hline & Bioheart & 5.8 & $-5 \%$ & $19-\mathrm{Feb}$ \\
\hline \multirow[t]{7}{*}{ Venture capital } & Company & Amount invested ( $\$$ millions) & Round number & Date closed \\
\hline & Affimed Therapeutics & 40.7 & 2 & $20-\mathrm{Feb}$ \\
\hline & Alder Biopharmaceuticals & 40.0 & 3 & 11-Jan \\
\hline & Pieris & 38.6 & 2 & 27-Mar \\
\hline & Endotis Pharma & 36.1 & 2 & 23-Jan \\
\hline & Ocera Therapeutics & 35.5 & 3 & $20-F e b$ \\
\hline & PanGenetics & 34.9 & 3 & 5-Mar \\
\hline \multirow[t]{6}{*}{ Mergers and acquisitions } & Target & Acquirer & Value (\$ millions) & Date announced \\
\hline & CollaGenex Pharmaceuticals & Galderma & 420 & $26-\mathrm{Feb}$ \\
\hline & CoGenesys & Teva Pharmaceutical Industries & 400 & 22-Jan \\
\hline & Warburg Pincus & Lifecore Biomedical & 329 & 15-Jan \\
\hline & Encysive Pharmaceuticals & Pfizer & 195 & 20-Feb \\
\hline & AppTec & WuXi Pharmatech & 151 & 4-Jan \\
\hline \multirow[t]{9}{*}{ Licensing/collaboration } & Researcher & Investor & Value ( $\$$ millions) & Deal description ${ }^{\mathrm{b}}$ \\
\hline & Isis Pharmaceuticals & Genzyme & 1,925 & Develop mipomersen and follow-on compounds to treat high cholesterol and thyroid cancers \\
\hline & Amgen & Takeda Pharmaceuticals & 1,177 & Received Japanese rights to 12 compounds and became the worldwide partner on motesanib \\
\hline & Addex Pharmaceuticals & Merck & 702 & Develop and market ADX63365 to treat schizophrenia and other undisclosed indication \\
\hline & Acceleron Pharma & Celgene & 560 & $\begin{array}{l}\text { Develop and commercialize ACE-011 to treat cancer, including breast and ovarian cancers, and } \\
\text { cancer-related bone loss }\end{array}$ \\
\hline & Kyowa Hakko Kogyo & Amgen & 520 & $\begin{array}{l}\text { Develop and commercialize KW-0761 for all noncancer indications outside of Asia } \\
\text { Deve }\end{array}$ \\
\hline & Dyax & Sanofi-Aventis & 500 & $\begin{array}{l}\text { Develop and commercialize DX-2240, a human monoclonal antibody targeting Tie1 in preclinical } \\
\text { development to treat cancer }\end{array}$ \\
\hline & Sepracor & Nycomed & 430 & $\begin{array}{l}\text { Develop and commercialize ciclesonide to treat asthma and seasonal allergic rhinitis } \\
\text { Deme }\end{array}$ \\
\hline & Amira Pharmaceuticals & GlaxoSmithKline & 425 & $\begin{array}{l}\text { Develop, manufacture and commercialize 5-lipoxygenaseactivating protein (FLAP) inhibitors for } \\
\text { respiratory/cardiovascular disease }\end{array}$ \\
\hline
\end{tabular}




\section{Erratum: HIV vaccine controversy}

\section{K S Jayaraman}

Nat. Biotechnol.26, 256 (2008); published online 7 March 2008; corrected after print 11 July 2008

In the version of this article initially published, the author reported that "trial participants now test seropositive for HIV and are 'unable to convince their employers that their HIV status was vaccine induced'” In fact, none of the trial participants tested positive for HIV. The error has been corrected in the HTML and PDF versions of the article.

\section{Erratum: Response to HIV vaccine trials in India}

\section{K S Jayaraman}

Nat. Biotechnol. 26, 496 (2008); published online 8 May 2008; corrected after print 11 July 2008

In the version of this article initially published, the author stated in his response to a letter from Seth Berkley that the results of IAVI's AIDS vaccine trials in Belgium and Germany were "not given to trial subjects and fresh consent obtained." This is incorrect. The European data were shared with trial subjects in India and they were reminded of their option to withdraw from the trial at any time. The error has been corrected in the HTML and PDF versions of the article.

\section{Erratum: Can ‘double blockbuster' strengthen Amgen's backbone?}

\section{Cormac Sheridan}

Nat. Biotechnol. 26, 361-363 (2008); published online 7 April 2008; corrected after print 7 August 2008

In the version of this article initially published, in Table 1, page 362, Protelos was wrongly cited as strontium malonate; in fact, Protelos is the current brand name of strontium ranelate. Unlike strontium malonate, strontium ranelate is approved by the European Medicines Evaluation Agency (EMEA) for the treatment of post-menopausal osteoporosis and has been shown in published clinical trials to decrease the risk of vertebral, nonvertebral and hip fractures in post-menopausal osteoporosis. The error has been corrected in the HTML and PDF versions of the article.

\section{Erratum: Biotech slumps in Q1}

Stacy Lawrence

Nat. Biotechnol. 26, 486 (2008); published online 8 May 2008; corrected after print 7 August 2008

In the version of this article initially published, in the table titled "Notable Q1 biotech deals," under Mergers and acquisitions, Warburg Pincus was incorrectly given as the Target and Lifecore Biomedical as the Acquirer. In fact, Warburg Pincus was the Acquirer and Lifecore Biomedical the Target. The error has been corrected in the HTML and PDF versions of the article. 